\title{
Synthesis and preliminary ex vivo evaluation of the spasmolytic activity of 1,3-thiazolium- and 1,3,4-thiadiazolium-5-methylthio- and 5-thioacetate derivatives
}

JOSÉ A. S. LUIS ${ }^{1 *}$

THIAGO M. DE AQUINO²

BRUNO F. LIRA ${ }^{3}$

PETRÔNIO F. A. FILHO

MARCUS T. SCOTTI ${ }^{4}$

LUCIANA SCOTTI ${ }^{5}$

RICARDO O. DE MOURA

FRANCISCO J. B. MENDONÇA JUNIOR ${ }^{5 *}$

${ }^{1}$ Centro de Educação e Saúde

Universidade Federal de Campina Grande 58175-000, Cuité-PB, Brazil

2 Instituto de Química e Biotecnologia Universidade Federal de Alagoas 57072-970, Maceió-AL, Brazil

${ }^{3}$ Departamento de Química, Universidade Federal da Paraíba, 58051-900

João Pessoa-PB, Brazil

${ }^{4}$ Departamento de Engenharia e Meio Ambiente, Universidade Federal da Paraíba Campus IV, 58297-000, Rio Tinto-PB, Brazil

${ }^{5}$ Departamento de Ciências Biológicas

Universidade Estadual da Paraíba

CCBSA, João Pessoa-PB 58070-450

Brazil
Seven new compounds have been synthetized in satisfactory yields (51-78\%) through the treatment of mesoionic 1,3-thiazolium-5-thiolate (4a-d) and 1,3,4-thiadiazolium-5-thiolate $\mathbf{( 1 0 a , b )}$ with chloroacetic acid or methyl iodide: 1,3,4-thiadiazolium-5-methylthio- (11) and 5-thioacetate (12). The structure of the title compounds was elucidated by elemental analysis, IR, ${ }^{1} \mathrm{H}$ and ${ }^{13} \mathrm{C}$ NMR spectroscopy. The newly synthesized compounds 5a, 6a, 11 and 12 were evaluated for their ex vivo spasmolytic potential on four isolated smooth muscles (rat aorta and uterus, guinea pig ileum and trachea) and compared with scopolamine. Some of the compounds exhibited potent spasmolytic activity equal to or stronger than scopolamine.

Keywords: 1,3-thiazolium, 1,3,4-thiadiazolium, mesoionic derivatives, spasmolytic activity

\footnotetext{
* Correspondence; e-mail: franciscojbmendonca@yahoo.com.br; joseasl@ufcg.edu.br
} 
J. A. S. Luis et al.: Synthesis and preliminary ex vivo evaluation of the spasmolytic activity of 1,3-thiazolium- and 1,3,4-thiadiazolium5-methylthio- and 5-thioacetate derivatives, Acta Pharm. 64 (2014) 233-245.

For decades, mesoionic compounds have attracted the interest of researchers around the world, either due to their peculiar chemical characteristics or the large number of biological activities provided by this class of substances (1). In 1996, mesoionic compounds were defined as planar five-membered heterocyclic betaines with, at least, one side-chain whose $\alpha$-atom is also in the ring plane with dipole moments of the order of 5 D. Electrons are delocalized over two regions separated by what are essentially single bonds. One region which includes the $\alpha$-atom of the side-chain is associated with the HOMO and negative $\pi$-charge whereas the other is associated with the LUMO and positive $\pi$-charge (2).

Due to their structural characteristics and properties, mesoionic compounds have attracted attention of many researchers in two major areas: photonics and non-linear optical studies (3-6) and medicinal chemistry. In the latter area, the literature describes a wide range of biological activities associated with this class of compounds, including, among others, analgesic, anti-inflammatory, anticancer, antimicrobial, antihypertensive, antiplatelet, thrombolytic, trypanocidal and leishmanicidal activities (7-13).

Continuing our studies on physical, chemical and biological properties of mesoionic derivatives, we report here the synthesis and structural elucidation of methylthio- and thioacetate- derivatives of the mesoionic systems 1,3-thiazolium-5-thiolate and 1,3,4thiadiazolium-5-thiolate along with their spasmolytic effects on isolated smooth muscles.

\section{EXPERIMENTAL}

\section{Reagents and general procedures}

All reagents and solvents used were commercially obtained (Sigma-Aldrich, Brazil) and used without further purification. The course of reactions was monitored by TLC on 0.25 -mm silica gel plates $\left(60 \mathrm{~F}_{254}\right.$, Merck, Germany). Hexane/chloroform mixtures were used as eluents. The final products were purified by column chromatography using neutral alumina (Merck) and the same eluents as used for TLC. The compounds were purified by recrystallization. Melting points were measured on a platinum plate in a Koffler apparatus coupled with a Carl-Zeiss microscope and are uncorrected. Elemental analyses were performed using an EA 1110 CHNS-O elemental analyzer (CE instruments, UK). The results were found to be in accord $( \pm 0.4 \%)$ with the calculated values. IR spectra were obtained on a Bomen-Michelson IFS 66 spectrometer (Bruker, USA) using KBr discs. NMR spectra were recorded on a VARIAN spectrometer UNITY PLUS (Varian, USA) with a 5-mm probe with a channel magnetic field gradient operating at $200 \mathrm{MHz}$ for ${ }^{1} \mathrm{H}$ $\mathrm{NMR}$ and $50 \mathrm{MHz}$ for ${ }^{13} \mathrm{C}$ NMR, using tetramethylsilane as internal standard. Chemical shifts are reported in ppm $(\delta)$, and coupling constants $(J)$ are reported in Hz. Spectral, physical and analytical data of all newly synthesized compounds are listed in Tables I and II.

\section{General synthesis procedure}

5-Methylthio $(5 a-c, 11)$ and 5-thioacetate $(6 a, b, 12)$ derivatives. - An equimolar mixture of mesoionic compounds $[(\mathbf{4} \mathbf{a}-\mathbf{d}$ or $\mathbf{1 0 a}, \mathbf{b}$, synthesized according to previous procedures (14, 
J. A. S. Luis et al.: Synthesis and preliminary ex vivo evaluation of the spasmolytic activity of 1,3-thiazolium- and 1,3,4-thiadiazolium5-methylthio- and 5-thioacetate derivatives, Acta Pharm. 64 (2014) 233-245.

15)] suspended in absolute ethanol and methyl iodide (for methylthio derivatives $5 \mathbf{a}-\mathbf{c}, \mathbf{1 1}$ ) or chloroacetic acid (for thioacetate derivatives $\mathbf{6 a}, \mathbf{b}, \mathbf{1 2}$ ) was stirred under room temperature until the observed color change to pale yellow (around 2 hours). The solvent was evaporated under reduced pressure and the solid residue obtained was recrystallized from ethanol/diethyl ether 1:1, affording pure crystals of 2-(4-chlorophenyl)-3- $N$-methyl-4-phenyl-1,3-thiazolium-5-methylthio iodide (5a), 2-(4-chlorophenyl)-3-N-methyl-4-(isopropyl-phenyl)-1,3-thiazolium-5-methylthio iodide (5b), 2-(4-chlorophenyl)-3- $N$-methyl-4-(metoxyphenyl)-1,3-thiazolium-5-methylthio iodide (5c), 2-(4-chlorophenyl)-3-methyl-4-phenyl-1,3-thiazolium-5-thioacetate (6a), 2-(4-trifluoromethyl-phenyl)-3- $N$-methyl-4-(isopropyl-phenyl)-1,3-thiazolium-5-thioacetate (6b), 2-(4-chlorophenyl)-3-phenyl-1,3,4-thiadiazolium-5-methylthio iodide (11) and 2,3-diphenyl-1,3,4-thiadiazolium-5-thioacetate (12) (Schemes 1 and 2).

\section{Animals}

Adult guinea-pigs of both sexes (Cavia porcellus, 300-500 g), male and female Wistar rats (Rattus norvegicus, 200-350 g), obtained from the Thomas George Biotery, Laboratório de Tecnologia Farmacêutica of the Federal University of Paraiba, were used. The animals were submitted to the following conditions: $12 \mathrm{~h}$ light/12 h dark cycle (lights on: 06:00-18:00 h), filtered conditioned air, $23 \pm 2{ }^{\circ} \mathrm{C}, 50-70 \%$ humidity, sterilized bed; Purina ${ }^{\circledR}$ pellets (Nestle, Brazil) and drinking sterilized water ad libitum were used. All sets of experiments were carried out in the period from 7:00 to 14:00 $\mathrm{h}$.

Animal handling and procedures were performed according to international guidelines for the use and care of laboratory animals (National Research Council, 1996). The experimental procedure was evaluated and approved by the Ethics Committee in Animal Research (CEPA) of the Federal University of Paraiba, Brazil.

\section{Drugs and reagents}

Carbamylcholine chloride (carbachol), oxytocin, histamine hydrochloride, acetylcholine chloride, arachidonic acid (AA), L-(-)-phenylephrine hydrochloride, (-)-scopolamine hydrochloride and cremophor, macrogol glycerol ricinoleate, non-ionic polyethoxylated detergent were purchased from Sigma-Aldrich Co. All salts for the organ bath solutions and reagents were purchased from Vetec (Rio de Janeiro, RJ, Brazil). Stock-solutions of all chemicals were prepared in distilled water. Compounds 5a, 6a, 11 and 12 were dissolved in cremophor. All stock-solutions were stored at $-20{ }^{\circ} \mathrm{C}$, and the dilutions were made fresh on the day of the experiment.

Experimental procedures for the study of the spasmolytic activity of the compounds were conducted similarly as described by Lima et al. (16) and are described below.

Tissue preparation and rat aorta and effects on the tonic contractions induced by phenylephrine. - Male Wistar rats (250-350 g) were killed by stunning and bleeding, their thoracic aorta was quickly removed and placed in Krebs' solution with $\mathrm{pH}$ adjusted to 7.4 with $1 \mathrm{~mol} \mathrm{~L}^{-1} \mathrm{HCl}$, continuously bubbled with a gas mixture $\mathrm{O}_{2} / \mathrm{CO}_{2}(95: 5, V / V)$. Fat and connective tissues surrounding the aorta were removed, and the aorta was cut into rings (3-4 mm length). Aortic rings were then suspended between two stainless steel wires in an organ chamber containing $6 \mathrm{~mL}$ of Krebs'solution. One of the wires was an- 
J. A. S. Luis et al.: Synthesis and preliminary ex vivo evaluation of the spasmolytic activity of 1,3-thiazolium- and 1,3,4-thiadiazolium5-methylthio- and 5-thioacetate derivatives, Acta Pharm. 64 (2014) 233-245.

chored in the organ chamber and the other was connected to a force-displacement transducer (Model 7003, UgoBasile, Italy). Isometric tensions of arterial tissues were recorded on a polygraph.

Two submaximal tonic responses to phenylephrine $(1 \mathrm{mmol} \mathrm{L}-1)$, which stabilized in 12-15 minutes, were initially obtained. During the tonic phase of the third response to phenylephrine, each of the test compounds $(5 \mathbf{a}, \mathbf{6 a}, \mathbf{1 1}$ and 12) and scopolamine hydrochloride (positive control) were added individually in a concentration of $10^{-4} \mathrm{~mol} \mathrm{~L}^{-1}$, and the contraction was measured again. The percentage of inhibition of the contraction was calculated by comparing the response in the absence $(100 \%)$ and in the presence of each tested compound and control.

\section{Rat uterus and effecst on the phasic contractions induced by oxytocin}

Virgin female Wistar rats (200-280 g) estrogenized with $1 \mathrm{mg} \mathrm{kg}^{-1}$ of estradiol benzoate were used. The animals were killed by decapitation $24 \mathrm{~h}$ after injection and both uterine horns were extracted and cleaned of adherences. Longitudinal strips, approximately $2-3 \mathrm{~cm}$, were placed vertically in 6-mL isolated organ baths containing Locke Ringer solution. In the same way, Locke Ringer solution was used without calcium and was bubbled continuously with a gas mixture $\mathrm{O}_{2} / \mathrm{CO}_{2}(95: 5, \mathrm{~V} / \mathrm{V})$ and maintained $32{ }^{\circ} \mathrm{C}$. The $\mathrm{pH}$ was adjusted to 7.4 with $1 \mathrm{~mol} \mathrm{~L}^{-1} \mathrm{HCl}$. Each uterine horn was subjected to a resting tension of $1 \mathrm{~g}$ and was allowed to equilibrate for at least 30-45 min before the drugs were added to organ baths. Phasic contractions were recorded using isotonic levers coupled to kymographs and smoked drums (DTF, Brazil).

Strips from non-pregnant and estrogenized rat uterus were contracted with $10 \mathrm{mIU}$ $\mathrm{ml}^{-1}$ of oxytocin and after $10 \mathrm{~min}$ from washout a new contraction was elicited by the agonist and the mean of the two contractions was considered as control (100\%). Before the third contraction, each of the test compounds (5a, 6a, 11 and 12) and scopolamine hydrochloride (positive control) were added individually to the organ bath, in a concentration of $10^{-4} \mathrm{~mol} \mathrm{~L}-1$, and the contraction was measured again after $10 \mathrm{~min}$. Inhibition was measured by comparing the response before and after addition of the agonist in the presence of the test compound and control. The drugs were subsequently washed-out and the recovery from contractions elicited by each drug and control was observed.

Guinea-pig ileum and effects on histamine-induced contractions. - To perform studies, the guinea-pig ileum was prepared according to Daniel et al. (17). Guinea-pigs (300-500 g) were killed by cervical dislocation, exsanguinated and the ileum was immediately removed. Terminal portions, $3 \mathrm{~cm}$ long, were used after discarding the $10-\mathrm{cm}$ portion close to the ileocaecal junction. The tissues were placed vertically in $6 \mathrm{~mL}$ isolated organ baths containing modified Krebs' solution of the following composition (mmol L-1): $\mathrm{NaCl}$ (117.0), $\mathrm{KCl}$ (4.7), $\mathrm{CaCl}_{2}$ (2.5), $\mathrm{MgSO}_{4}$ (1.3), $\mathrm{NaH}_{2} \mathrm{PO}_{4}$ (1.2), $\mathrm{NaHCO}_{3}$ (25.0), glucose (11.0), bubbled with a gas mixture $\mathrm{O}_{2} / \mathrm{CO}_{2}(95: 5, V / V)$ and maintained at $37^{\circ} \mathrm{C} ; \mathrm{pH}$ was adjusted to 7.4 with $1 \mathrm{~mol} \mathrm{~L}^{-1} \mathrm{HCl}$. Tension changes were recorded with an isometric force transducer (Model 7003, UgoBasile) counter balanced by $1 \mathrm{~g}$ loading, connected to a polygraph (Gemini 7070, UgoBasile). Phasic contractions were recorded using isotonic 
J. A. S. Luis et al.: Synthesis and preliminary ex vivo evaluation of the spasmolytic activity of 1,3-thiazolium- and 1,3,4-thiadiazolium5-methylthio- and 5-thioacetate derivatives, Acta Pharm. 64 (2014) 233-245.

levers coupled to kymographs and smoked drums (DTF). The tissues were allowed to stabilize for $30 \mathrm{~min}$ at a resting tension of $1 \mathrm{~g}$. During the stabilization period, the modified Krebs solution was changed every $10 \mathrm{~min}$ to avoid accumulation of metabolites (18).

At the beginning of each experiment, the reactivity of tissue preparation was tested with $40 \mathrm{mmol} \mathrm{L}-1 \mathrm{KCl}$. After washout and 15-min recovery in modified Krebs solution, two submaximal tonic responses to histamine $\left(1 \mathrm{mmol} \mathrm{L}^{-1}\right)$, which stabilized in 12-15 minutes, were obtained initially. Compounds 5a, 6a, 11 and 12 and scopolamine hydrochloride (positive control), were added individually $\left(10^{-4} \mathrm{~mol} \mathrm{~L}^{-1}\right)$ after an incubation period of $15 \mathrm{~min}$; the third response to histamine $\left(1 \mathrm{mmol} \mathrm{L}^{-1}\right)$ was induced in the presence of the test compound and control. The tissue was washed when the agonist response returned to the resting level. Inhibition was measured by comparing the response before (100\%) and after addition of the test-compounds and control in the organ bath.

Guinea-pig trachea and effects on the contractions induced by carbachol. - Guinea-pigs of both sexes (300-500 g), were killed by cervical dislocation, the abdomen was opened and the trachea was quickly removed and dissected free of adhering fat and connective tissue. From every trachea, four rings containing three to four cartilaginous segments were obtained. Each tracheal ring was hung between two hooks inserted into the lumen, and placed in a 6-mL organ bath containing Krebs' solution maintained at $\mathrm{pH} 7.4,37^{\circ} \mathrm{C}$, and bubbled with a gas mixture $\mathrm{O}_{2} / \mathrm{CO}_{2}(95: 5, V / V)$. Tracheal preparations were allowed to stabilize for $60 \mathrm{~min}$ at a resting tension of $1 \mathrm{~g}$ basal tension. At the beginning of each experiment, $\mathrm{KCl} 60 \mathrm{mmol} \mathrm{L}^{-1}$ was added once to evaluate the viability of the tissue. The $\mathrm{KCl}$ contraction was taken into account for normalization of all subsequent responses to the different agonists. After washout and 30 min recovery in Krebs solution, contractions were evoked by adding carbachol $\left(10^{-6} \mathrm{~mol} \mathrm{~L}^{-1}\right)$. The integrity of the functional epithelium was verified by the addition of arachidonic acid (AA) to the organ bath in the concentration of $10^{-4} \mathrm{~mol} \mathrm{~L}^{-1}$ (19). During the tonic phase of the first contractile response induced by $10^{-6} \mathrm{~mol} \mathrm{~L}^{-1}$ carbachol, tracheal rings that showed superior relaxations to $50 \%$ (in relation to the force of initial contraction) were considered with epithelium. Isometric contractions were measured with a force transducer (World Precision Instruments, Model FORT-10, USA) coupled to an amplifier (World Precision Instruments, Model TMB4M, USA), connected to a A/D converter into a PC running Biomed ${ }^{\circledR}$ software v.Rv2 (BioData, Ribeirao Preto, Brazil).

After the resting period, the tracheal rings were contracted with carbachol $\left(10^{-6} \mathrm{~mol}\right.$ $\mathrm{L}^{-1}$ ) and the isometric tension was recorded. In second carbachol-induced stable contraction, compounds 5a, 6a, 11 and 12 and scopolamine hydrochloride (positive control, 10-5 mol L-1) were added individually to the organ bath. The inhibition was measured by comparing the response before and after addition of the agonist in the presence of the test compounds and scopolamine in the organ bath.

\section{Statistical analysis}

All data were statistically analyzed using Student's $t$-test and the differences were considered significant when $p<0.05$. 


\section{RESULTS AND DISCUSSION}

\section{Chemistry}

Two classes of compounds were obtained in this work, the 1,3-thiazolium-5-thiolate and the 1,3,4-thiadiazolium-5-thiolate derivatives. 1,3-Thiazolium-5-thiolate derivatives were obtained through a synthetic pathway started by a Strecker reaction of benzaldehyde derivatives $(\mathbf{1 a}-\mathbf{c})$ with sodium cyanide and affording $\mathrm{C}$-aryl- $\mathrm{N}$-methyl-glycines $(2 \mathbf{a}-\mathbf{c})$. These were aroylated to give $\mathrm{C}$-aryl- $N$-aroyl- $N$-methyl-glycines $(3 \mathbf{a}-\mathbf{d})$. The mesoionics $4 \mathbf{a}-\mathbf{d}$ were obtained via cyclodehydratation to non-isolated 1,3-oxazolium-5-olates, followed by a 1,3-dipolar cycloaddition and cycloreversion sequence induced by $\mathrm{CS}_{2}$, and elimination of $\mathrm{CO}_{2}$ (14) (Scheme 1).

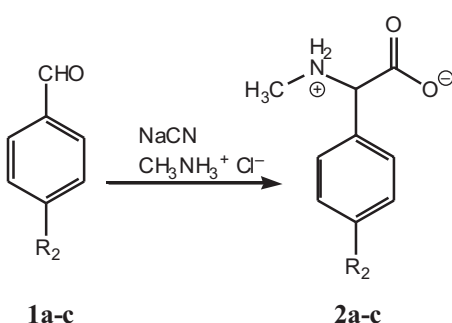<smiles>[R]C1=CCC(C(=O)N(C)C(C(=O)[O-])c2ccc([R2])cc2)C=C1</smiles><smiles>[R]c1ccc(C2=[SH](=S)C(c3ccc([R])cc3)N(C)C2c2ccc([R])cc2)cc1</smiles>

Scheme 1 
The synthesis of the 1,3,4-thiadiazolium-5-thiolate mesoionics (10a,b) started through the reaction of phenylhydrazine (7) with $\mathrm{CS}_{2}$ and $\mathrm{KOH}$ to give potassium -phenyl-carbazoate (8). This was aroylated with benzoyl chloride and 4-chlorobenzoyl chloride $(\mathbf{9 a}, \mathbf{b})$ affording the mesoionic system (10a,b) (15) (Scheme 2).

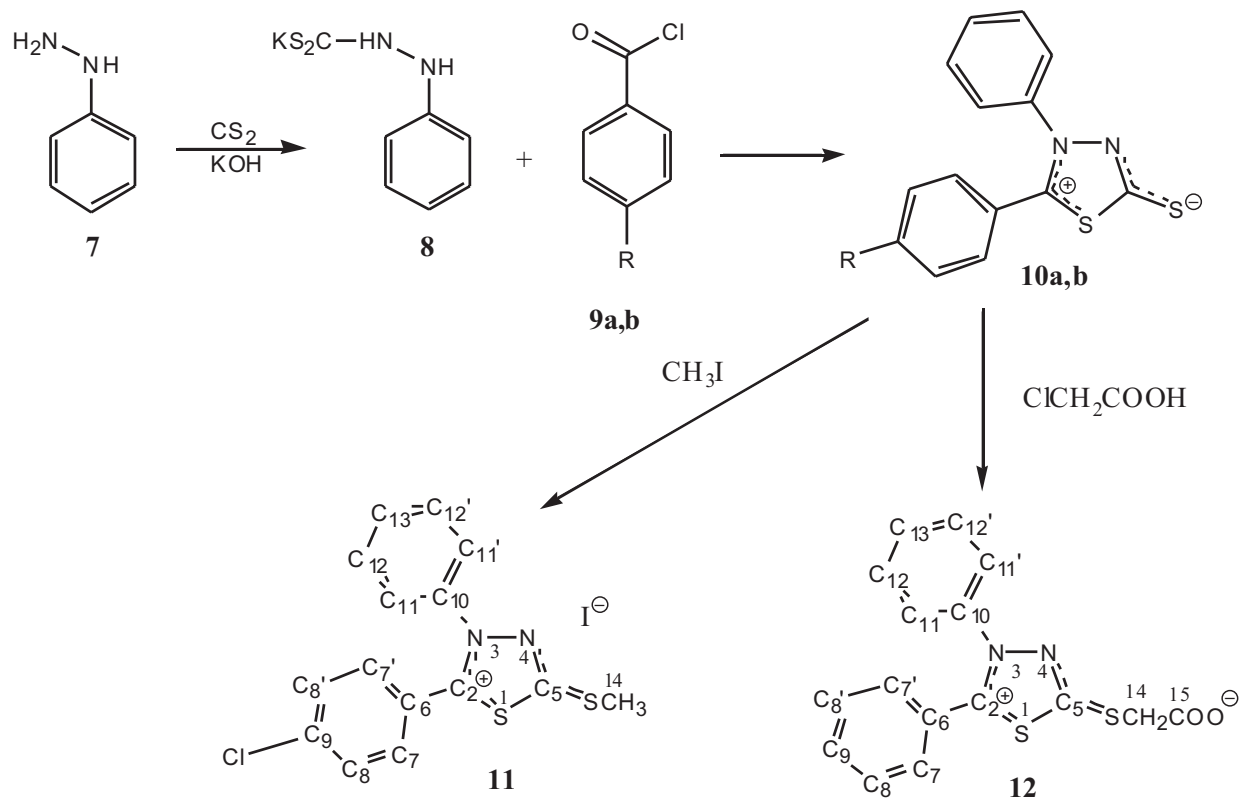

Scheme 2

The last reaction step was conversion of the two mesoionic systems $(\mathbf{4} \mathbf{a}-\mathbf{d}$ and $\mathbf{1 0 a}, \mathbf{b})$ into their respective salts, through their treatment with chloroacetic acid or methyl iodide. This procedure gave the new seven compounds derived from mesoionics $\mathbf{5 a}-\mathbf{c}, \mathbf{6} \mathbf{a}, \mathbf{b}$, 11 and 12, which were characterized based on their physical, analytical and spectral data, which were in full agreement with the proposed structures (Tables I, II).

According to a previous work (14), assignments of the mesoionic ring carbon atoms C-3, C-4 and C-5 of the 1,3-thiazolium-5-thiolate system, and C-2 and C-5 of the 1,3,4-thiadiazolium-5-thiolate ring are of special importance for unequivocal structural elucidation. Chemical shifts of these carbon atoms are influenced by shielding in the HOMO region and deshielding in the LUMO region.

For compounds $5 \mathrm{a}-\mathbf{c}, \mathrm{C}-4, \mathrm{C}-2$ and C-5 were the most deshielding carbon atoms. Assignments of C-4 at $\delta$ 139.9, 149.9 and 148.9 ppm to $\mathbf{5 a}, \mathbf{5 b}$ and $\mathbf{5 c}$, respectively, are considered to be due to shielding when compared to C-5 at $\delta 167.9,168.0$ and $167.2 \mathrm{ppm}$, respectively. As described by Lira et al. (14), electron delocalization in the HOMO region restricts negative $\pi$-charge to $\mathrm{C}-4$. Chemical shifts at $\delta 149.3,152.6$ and $161.4 \mathrm{ppm}(\mathbf{5 a}, 5 \mathbf{b}$ and $5 c$, respectively) were attributed to $\mathrm{C}-2$, and were influenced by deshielding in the LUMO region in which positive $\pi$-charge is delocalized. 
J. A. S. Luis et al.: Synthesis and preliminary ex vivo evaluation of the spasmolytic activity of 1,3-thiazolium- and 1,3,4-thiadiazolium5-methylthio- and 5-thioacetate derivatives, Acta Pharm. 64 (2014) 233-245.

Table I. Physical and analytical data of compounds $5 a-c, 6 a-b, 11$ and 12

\begin{tabular}{|c|c|c|c|c|c|c|c|c|}
\hline \multirow{2}{*}{ Compd. } & \multirow{2}{*}{$\begin{array}{l}\text { Molecular } \\
\text { formula }\end{array}$} & \multirow{2}{*}{$M_{\mathrm{r}}$} & \multirow{2}{*}{$\begin{array}{l}\text { M. p. } \\
\left({ }^{\circ} \mathrm{C}\right)\end{array}$} & \multirow{2}{*}{$\begin{array}{c}\text { Yield } \\
(\%)\end{array}$} & \multicolumn{4}{|c|}{ Analysis (calcd./found, \%) } \\
\hline & & & & & $\mathrm{C}$ & $\mathrm{H}$ & $\mathrm{N}$ & $S$ \\
\hline $5 a$ & $\mathrm{C}_{17} \mathrm{H}_{15} \mathrm{ClINS}_{2}$ & 458.94 & 189-190 & 71 & $\begin{array}{c}44.20 / \\
44.40\end{array}$ & $\begin{array}{c}2.96 / \\
3.16\end{array}$ & $\begin{array}{r}2.74 / \\
2.94\end{array}$ & $\begin{array}{c}11.93 / \\
12.01\end{array}$ \\
\hline $5 b$ & $\mathrm{C}_{20} \mathrm{H}_{21} \mathrm{ClINS}_{2}$ & 500.99 & $180-181$ & 69 & $\begin{array}{c}47.76 / \\
47.36\end{array}$ & $\begin{array}{l}4.18 / \\
3.91\end{array}$ & $\begin{array}{c}2.79 / \\
2.85\end{array}$ & $\begin{array}{c}12.73 / \\
12.55\end{array}$ \\
\hline $5 c$ & $\mathrm{C}_{18} \mathrm{H}_{17}$ ClINOS & 489.95 & 199-200 & 78 & $\begin{array}{c}43.24 / \\
43.63\end{array}$ & $\begin{array}{c}3.40 / \\
3.15\end{array}$ & $\begin{array}{c}2.80 / \\
2.56\end{array}$ & $\begin{array}{r}12.81 / \\
12.66\end{array}$ \\
\hline $6 a$ & $\mathrm{C}_{18} \mathrm{H}_{14} \mathrm{ClNO}_{2} \mathrm{~S}_{2}$ & 375.02 & 187 & 61 & $\begin{array}{c}57.46 / \\
57.24\end{array}$ & $\begin{array}{l}3.72 / \\
3.92\end{array}$ & $\begin{array}{c}3.72 / \\
3.85\end{array}$ & $\begin{array}{r}17.03 / \\
16.89\end{array}$ \\
\hline $6 b$ & $\mathrm{C}_{22} \mathrm{H}_{20} \mathrm{~F}_{3} \mathrm{NO}_{2} \mathrm{~S}_{2}$ & 417.06 & 186-187 & 51 & $\begin{array}{c}58.47 / \\
58.53\end{array}$ & $\begin{array}{c}4.43 / \\
4.58\end{array}$ & $\begin{array}{r}3.10 / \\
3.12\end{array}$ & $\begin{array}{c}14.17 / \\
13.99\end{array}$ \\
\hline 11 & $\mathrm{C}_{16} \mathrm{H}_{12} \mathrm{~N}_{2} \mathrm{O}_{2} \mathrm{~S}_{2}$ & 445.92 & $173-174$ & 78 & $\begin{array}{c}39.82 / \\
40.01\end{array}$ & $\begin{array}{r}2.45 / \\
2.69\end{array}$ & $\begin{array}{c}6.11 / \\
6.27\end{array}$ & $\begin{array}{c}13.63 / \\
14.03\end{array}$ \\
\hline 12 & $\mathrm{C}_{15} \mathrm{H}_{12} \mathrm{ClIN}_{2} \mathrm{~S}_{2}$ & 362.00 & $188-189$ & 61 & $\begin{array}{c}58.53 / \\
58.34\end{array}$ & $\begin{array}{c}3.66 / \\
3.27\end{array}$ & $\begin{array}{c}8.54 / \\
8.79\end{array}$ & $\begin{array}{c}19.51 / \\
19.30\end{array}$ \\
\hline
\end{tabular}

The ${ }^{1} \mathrm{H}$ NMR of $5 \mathrm{a}-\mathrm{c}$ had two intense and characteristics singlets integrating for $3 \mathrm{H}$ corresponding to the $N$-methyl and $S$-methyl groups. These singlets appeared at $\delta 3.81$ $(N-\mathrm{Me})$ and $2.49 \mathrm{ppm}(\mathrm{S}-\mathrm{Me})$ for $\mathbf{5 a}$, at $\delta 3.84(\mathrm{~N}-\mathrm{Me})$ and $2.50 \mathrm{ppm}(S-\mathrm{Me})$ for $\mathbf{5 b}$, and at $\delta 3.73(\mathrm{~N}-\mathrm{Me})$ and $2.40 \mathrm{ppm}(\mathrm{S}-\mathrm{Me})$ for $\mathbf{5 c}$. For $\mathbf{5 c}$, an additional singlet, integrating for $3 \mathrm{H}$ at $\delta 3.75 \mathrm{ppm}$, corresponds to the $O$-methyl group.

For the 5-thioacetate derivatives (6a and $\mathbf{6 b})$, the signals in the ${ }^{13} \mathrm{C}$ NMR at $\delta 141.3$, 152.9 and $171.8 \mathrm{ppm}$ (for 6a) and at $\delta 141.6,153.0$ and $169.8 \mathrm{ppm}$ (for $\mathbf{6 b}$ ) were associated with carbons C-4, C-2 and C-5, respectively. Signals at $\delta 39.3$ and $41.0 \mathrm{ppm}$ were attributed to the carbons of the methylene groups (C-15), and those at $\delta 41.6$ and $40.7 \mathrm{ppm}$ to the carbons of the $N$-methyl group (C-10). The most deshielding signals, appearing at $\delta$ 172.0 and $173.9 \mathrm{ppm}$, were assigned to the carbons of the carboxylate group $\left(\mathrm{COO}^{-}\right)$. The ${ }^{1} \mathrm{H}$ NMR spectra of $\mathbf{6 a}$ and $\mathbf{6 b}$, present two intense singlets, one of them integrating for $3 \mathrm{H}$ at $\delta 3.79$ (for $\mathbf{6 a}$ ) and $3.46 \mathrm{ppm}$ (for $\mathbf{6 b}$ ) corresponding to $N$-methyl hydrogens, and the other integrating for $2 \mathrm{H}$ at $\delta 3.75$ (for $\mathbf{6 a}$ ) and $3.67 \mathrm{ppm}$ (for $\mathbf{6 b}$ ), corresponding to the methylene group $\left(\mathrm{S}-\mathrm{CH}_{2}-\mathrm{COO}^{-}\right)$.

For $5 \mathbf{b}$ and $\mathbf{6 b}$, septets at $\delta 2.97(5 \mathbf{b})$ and $2.89 \mathrm{ppm}(\mathbf{6 b})$ integrating for $1 \mathrm{H}$ and a doublet integrating for $6 \mathrm{H}$ at $\delta 1.27(5 \mathbf{b})$ and $1.23 \mathrm{ppm}(\mathbf{6 b})$ indicate the presence of the isopropyl residues.

${ }^{13} \mathrm{C}$ NMR data of 1,3,4-thiadiazolium derivatives shows signals at $\delta 168.2$ and 169.5 ppm (for 12), and at $\delta 173.2$ and $173.5 \mathrm{ppm}$ (for 11) attributed, respectively, to the carbons C-2 and C-5. Chemical shifts ${ }^{13} \mathrm{C}$ at $\delta 17.4$ (for 11), and at $\delta 35.8$ and $173.2 \mathrm{ppm}$ (for 12) demonstrate unequivocally the presence of the 5-methylthio and 5-thioacetate groups in these molecules. The ${ }^{1} \mathrm{H}$ NMR data confirms these attributions show for $\mathbf{1 1}$ the presence of one singlet, integrating for $3 \mathrm{H}$, at $\delta 2.90 \mathrm{ppm}$, and for 12, one singlet, integrating for $2 \mathrm{H}$, at $\delta 3.97 \mathrm{ppm}$. 
J. A. S. Luis et al: Synthesis and preliminary ex vivo evaluation of the spasmolytic activity of 1,3-thiazolium- and 1,3,4-thiadiazolium5-methylthio- and 5-thioacetate derivatives, Acta Pharm. 64 (2014) 233-245.

Table II. Spectral data of compounds $5 \boldsymbol{a}-\boldsymbol{c}, 6 \boldsymbol{a}-\boldsymbol{b}, 11$ and 12

\begin{tabular}{|c|c|c|c|}
\hline Compd. & $\begin{array}{c}\mathrm{IR}(\mathrm{KBr}) \\
\left(v_{\max }, \mathrm{cm}^{-1}\right)\end{array}$ & ${ }^{1} \mathrm{H}$ NMR $(\delta, \mathrm{ppm})$ & ${ }^{13} \mathrm{C} \operatorname{NMR}(\delta, \mathrm{ppm})$ \\
\hline $5 a^{a}$ & $\begin{array}{l}3060,3029 \\
2996,1586 \\
1556,1094 \\
1067,1020\end{array}$ & $\begin{array}{l}2.49(\mathrm{~s}, 3 \mathrm{H}, \mathrm{H}-15), 3.81(\mathrm{~s}, 3 \mathrm{H}, \\
\mathrm{H}-10), 7.52\left(\mathrm{~m}, 5 \mathrm{H}, \mathrm{H}-12,12^{\prime}, 13,13^{\prime}\right. \\
\text { and } 14), 7.88\left(\mathrm{~d}, 2 \mathrm{H}, \mathrm{H}-7 \text { and } 7^{\prime}, J=\right. \\
8.2 \mathrm{~Hz}), 8.09\left(\mathrm{~d}, 2 \mathrm{H}, \mathrm{H}-8 \text { and } 8^{\prime}, J=\right. \\
8.2 \mathrm{~Hz})\end{array}$ & $\begin{array}{l}20.7(\mathrm{C}-15), 41.4(\mathrm{C}-10), 123.3(\mathrm{C}-11), \\
126.5(\mathrm{C}-9), 129.2(\mathrm{C}-14), 129.9(\mathrm{C}-13 \\
\left.\text { and } 13^{\prime}\right), 131.1\left(\mathrm{C}-12 \text { and } 12^{\prime}\right), 131.3 \\
\left(\mathrm{C}-7 \text { and } 7^{\prime}\right), 132.4\left(\mathrm{C}-8 \text { and } 8^{\prime}\right), 135.3 \\
(\mathrm{C}-6), 139.9(\mathrm{C}-4), 149.3(\mathrm{C}-2), 167.9 \\
(\mathrm{C}-5)\end{array}$ \\
\hline $5 b^{a}$ & $\begin{array}{l}3055,3023, \\
2960,2870, \\
1612,1514, \\
1293,1094 \\
1067,1020\end{array}$ & $\begin{array}{l}1.27\left(\mathrm{~d}, 6 \mathrm{H}, \mathrm{CH}\left(\mathrm{CH}_{3}\right)_{2}, J=7.0 \mathrm{~Hz}\right), \\
2.97\left(\mathrm{sept}, 1 \mathrm{H}, \mathrm{CH}\left(\mathrm{CH}_{3}\right)_{2}, J=6.2\right. \\
\mathrm{Hz}), 2.50(\mathrm{~s}, 3 \mathrm{H}, \mathrm{H}-15), 3.84(\mathrm{~s}, 3 \mathrm{H}, \\
\mathrm{H}-10), 7.39\left(\mathrm{~d}, 2 \mathrm{H}, \mathrm{H}-13 \text { and } 13^{\prime}, J=\right. \\
8.4 \mathrm{~Hz}), 7.56\left(\mathrm{~d}, 2 \mathrm{H}, \mathrm{H}-8 \text { and } 8^{\prime}, J=\right. \\
7.8 \mathrm{~Hz}), 7.79\left(\mathrm{~d}, 2 \mathrm{H}, \mathrm{H}-12 \text { and } 12^{\prime}, J\right. \\
=8.4 \mathrm{~Hz}), 8.08\left(\mathrm{~d}, 2 \mathrm{H}, \mathrm{H}-7 \text { and } 7^{\prime}, J\right. \\
=7.8 \mathrm{~Hz})\end{array}$ & $\begin{array}{l}20.7(\mathrm{C}-15), 23.7\left(\mathrm{CH}\left(\mathrm{CH}_{3}\right)_{2}\right), 34.1 \\
\left.\left(\mathrm{CH}\left(\mathrm{CH}_{3}\right)\right)_{2}\right), 41.4(\mathrm{C}-10), 123.8(\mathrm{C}-11), \\
140.1(\mathrm{C}-9), 123.5(\mathrm{C}-14), 127.5(\mathrm{C}-13 \\
\left.\text { and } 13^{\prime}\right), 130.0\left(\mathrm{C}-12 \text { and } 12^{\prime}\right), 131.1 \\
\left(\mathrm{C}-7 \text { and } 7^{\prime}\right), 132.4\left(\mathrm{C}-8 \text { and } 8^{\prime}\right), 135.2 \\
(\mathrm{C}-6), 149.9(\mathrm{C}-4), 152.6(\mathrm{C}-2), 168.0 \\
\text { (C-5). }\end{array}$ \\
\hline $5 c^{a}$ & $\begin{array}{l}3079,3043 \\
2989,2950 \\
2908,1610 \\
1597,1482 \\
1433,1302 \\
1251,1280\end{array}$ & $\begin{array}{l}2.40(\mathrm{~s}, 3 \mathrm{H}, \mathrm{H}-15), 3.73(\mathrm{~s}, 3 \mathrm{H}, \\
\mathrm{H}-10), 3.75\left(\mathrm{~s}, 3 \mathrm{H}, \mathrm{O}-\mathrm{CH}_{3}\right), 6.91(\mathrm{~d}, \\
\left.2 \mathrm{H}, \mathrm{H}-13 \text { e } 13^{\prime}, J=8.2 \mathrm{~Hz}\right), 7.42(\mathrm{~d}, \\
\left.2 \mathrm{H}, \mathrm{H}-8 \text { and } 8^{\prime}, J=7.8 \mathrm{~Hz}\right), 7.73(\mathrm{~d}, \\
\left.2 \mathrm{H}, \mathrm{H}-12 \text { and } 12^{\prime}, J=8.2 \mathrm{~Hz}\right), 8.04 \\
\left(\mathrm{~d}, 2 \mathrm{H}, \mathrm{H}-7 \text { and } 7^{\prime}, J=7.8 \mathrm{~Hz}\right)\end{array}$ & $\begin{array}{l}20.2(\mathrm{C}-15), 41.2(\mathrm{C}-10), 55.2\left(\mathrm{O}-\mathrm{CH}_{3}\right), \\
114.4\left(\mathrm{C}-13 \text { e } 13^{\prime}\right), 118.2(\mathrm{C}-14), 123.3 \\
(\mathrm{C}-11), 129.5\left(\mathrm{C}-12 \text { and } 12^{\prime}\right), 139.4 \\
(\mathrm{C}-9), 132.2\left(\mathrm{C}-7 \text { and } 7^{\prime}\right), 132.5(\mathrm{C}-8 \\
\left.\text { and } 8^{\prime}\right), 134.7(\mathrm{C}-6), 148.9(\mathrm{C}-4), 161.4 \\
(\mathrm{C}-2), 167.2(\mathrm{C}-5)\end{array}$ \\
\hline $6 a^{b}$ & $\begin{array}{l}2936,1719 \\
1593,1485 \\
1096\end{array}$ & $\begin{array}{l}3.75(\mathrm{~s}, 2 \mathrm{H}, \mathrm{H}-15), 3.79(\mathrm{~s}, 3 \mathrm{H}, \\
\mathrm{H}-10), 7.64-7.90(\mathrm{~m}, 9 \mathrm{H}, \mathrm{ArH})\end{array}$ & $\begin{array}{l}39.3(\mathrm{C}-15), 41.6(\mathrm{C}-10), 125.3(\mathrm{C}-7 \\
\left.\text { and } 7^{\prime}\right), 128.4(\mathrm{C}-11), 130.6(\mathrm{C}-8 \text { and } \\
\left.8^{\prime}\right), 131.3\left(\mathrm{C}-12 \text { and } 12^{\prime}\right), 131.7(\mathrm{C}-14), \\
132.7\left(\mathrm{C}-13 \text { and } 13^{\prime}\right), 132.9 \text { (C-6), } \\
133.8 \text { (C-9), } 141.3(\mathrm{C}-4), 152.9 \text { (C-2), } \\
171.8 \text { (C-5), } 172.0(\mathrm{C}-16)\end{array}$ \\
\hline $6 b^{b}$ & $\begin{array}{l}3027,2961, \\
2872,1712, \\
1506,1462, \\
1408,1323, \\
1129\end{array}$ & $\begin{array}{l}1.23\left(\mathrm{~d}, 6 \mathrm{H}, \mathrm{CH}\left(\mathrm{CH}_{3}\right)_{2}, J=7.2 \mathrm{~Hz}\right), \\
2.89\left(\mathrm{sept}, 1 \mathrm{H}, \mathrm{CH}\left(\mathrm{CH}_{3}\right)_{2}, J=6.4\right. \\
\mathrm{Hz}), 3.46(\mathrm{~s}, 3 \mathrm{H}, \mathrm{H}-10), 3.67(\mathrm{~s}, 2 \mathrm{H}, \\
\mathrm{H}-15), 7.29\left(\mathrm{~d}, 2 \mathrm{H}, \mathrm{H}-13 \text { and } 13^{\prime}, J=\right. \\
8.0 \mathrm{~Hz}), 7.44\left(\mathrm{~d}, 2 \mathrm{H}, \mathrm{H}-8 \text { and } 8^{\prime}, J=\right. \\
7.6 \mathrm{~Hz}), 7.83\left(\mathrm{~d}, 2 \mathrm{H}, \mathrm{H}-12 \text { and } 12^{\prime}, J\right. \\
=8.0 \mathrm{~Hz}) ; 8.16\left(\mathrm{~d}, 2 \mathrm{H}, \mathrm{H}-7 \text { e } 7^{\prime}, J=\right. \\
7.6 \mathrm{~Hz})\end{array}$ & $\begin{array}{l}23.4\left(\mathrm{CH}\left(\mathrm{CH}_{3}\right)_{2}\right), 34.0\left(\mathrm{CH}\left(\mathrm{CH}_{3}\right)_{2}\right), \\
40.7(\mathrm{C}-10), 41.0(\mathrm{C}-15), 120.8\left(\mathrm{CF}_{3}\right), \\
125.2\left(\mathrm{C}-8 \text { and } 8^{\prime}\right), 126.3(\mathrm{C}-13 \text { and } \\
\left.13^{\prime}\right), 126.8\left(\mathrm{C}-12 \text { and } 12^{\prime}\right), 127.7(\mathrm{C}-7 \\
\left.\text { and } 7^{\prime}\right), 129.5(\mathrm{C}-11), 130.2(\mathrm{C}-9), \\
133.6(\mathrm{C}-6), 141.6(\mathrm{C}-4), 151.64(\mathrm{C}-14), \\
153.0(\mathrm{C}-2), 169.8(\mathrm{C}-5), 173.9(\mathrm{C}-16)\end{array}$ \\
\hline $11^{\mathrm{b}}$ & $\begin{array}{l}3051,2970, \\
1585,1504, \\
1068,1015\end{array}$ & $\begin{array}{l}3.97(\mathrm{~s}, 2 \mathrm{H}, \mathrm{H}-14) \\
7.22-7.40(\mathrm{~m}, 10 \mathrm{H}, \mathrm{ArH})\end{array}$ & $\begin{array}{l}35.8(\mathrm{C}-14), 121.8(\mathrm{C}-6), 125.3(\mathrm{C}-12 \\
\left.\text { and } 12^{\prime}\right), 129.8\left(\mathrm{C}-8 \text { and } 8^{\prime}\right), 129.9 \\
\left(\mathrm{C}-11 \text { and } 11^{\prime}\right), 130.0(\mathrm{C}-13), 131.9 \\
(\mathrm{C}-9), 134.4\left(\mathrm{C}-7 \text { and } 7^{\prime}\right), 136.6(\mathrm{C}-10), \\
168.2(\mathrm{C}-5), 169.6(\mathrm{C}-2), 173.2(\mathrm{C}-15)\end{array}$ \\
\hline $12^{\mathrm{a}}$ & $\begin{array}{l}3056,1715 \\
1600,1490\end{array}$ & $\begin{array}{l}2.90(\mathrm{~s}, 3 \mathrm{H}, \mathrm{H}-14) \\
7.55-7.75(\mathrm{~m}, 9 \mathrm{H}, \mathrm{ArH})\end{array}$ & $\begin{array}{l}17.4(\mathrm{C}-14), 122.4(\mathrm{C}-6), 127.3 \text { (C-12 } \\
\left.\text { and } 12^{\prime}\right), 130.9(\mathrm{C}-13), 131.1 \text { (C-11 } \\
\left.\left.\text { and } 11^{\prime}\right), 133.1 \text { (C-7 and } 7^{\prime}\right), 133.3 \\
\left(\mathrm{C}-8 \text { and } 8^{\prime}\right), 138.5(\mathrm{C}-10), 141.7 \text { (C-9), } \\
173.2(\mathrm{C}-5), 173.5(\mathrm{C}-2)\end{array}$ \\
\hline
\end{tabular}

Multiplicities were indicated as follows: s (singlet); $d$ (doublet); $t$ (triplet), sept (septet) and m (multiplet).

a $\mathrm{CDCl}_{3} ;{ }^{\text {b }} \mathrm{CD}_{3} \mathrm{OD}$. 
J. A. S. Luis et al: Synthesis and preliminary ex vivo evaluation of the spasmolytic activity of 1,3-thiazolium- and 1,3,4-thiadiazolium5-methylthio- and 5-thioacetate derivatives, Acta Pharm. 64 (2014) 233-245.

The main vibrational bands of the title compounds are given in Table II. IR spectra showed absorption bands for all compounds at about $3079-2872 \mathrm{~cm}^{-1}$ characteristic of $\mathrm{C}-\mathrm{H}_{\mathrm{Ar}}$ and $\mathrm{C}-\mathrm{H}_{\mathrm{Aliph}}$ stretching vibrations, and at about $1612-1433 \mathrm{~cm}^{-1}$, characteristic of $\mathrm{C}=\mathrm{C}$ and $\mathrm{C}=\mathrm{N}$ mesoionic ring stretching. Compounds $\mathbf{6 a}, \mathbf{6 b}$ and 12 showed further intense characteristic absorption bands at 1719,1712 and $1715 \mathrm{~cm}^{-1}$, respectively, due to axial carbonyl deformation $(\mathrm{C}=\mathrm{O})$.

\section{Spasmolytic activity}

Compounds 5a, 6a, 11 and 12 were selected and evaluated for their spasmolytic activity on smooth muscle isolated from rats and guinea pigs and compared to scopolamine. The results are summarized in Table III.

The data presented in Table III show that all tested compounds were able to induce relaxation on muscles isolated from rats and guinea pigs in the presence of their

Table III. Spasmolytic activity of compounds 5a, 6a, 11 and 12 and scopolamine in smooth muscles induced by phenylephrine, carbachol, oxytocin and histamine

\begin{tabular}{|c|c|c|c|c|}
\hline Compound & Tissue & Agonist & Inhibition $(\%)^{\mathrm{a}}$ & Concentration $\left(\mathrm{mol} \mathrm{L}^{-1}\right)$ \\
\hline \multirow[t]{4}{*}{$5 a$} & Aorta & Phenylephrine & $55.5 \pm 1.2^{\mathrm{b}}$ & $10^{-4}$ \\
\hline & Trachea & Carbachol & $97.2 \pm 1.6^{\mathrm{b}}$ & $10^{-5}$ \\
\hline & Uterus & Oxytocin & $98.3 \pm 1.2^{b}$ & $10^{-4}$ \\
\hline & Ileum & Histamine & $45.3 \pm 1.4^{\mathrm{b}}$ & $10^{-4}$ \\
\hline \multirow[t]{4}{*}{$6 a$} & Aorta & Phenylephrine & $55.5 \pm 1.2^{\mathrm{c}}$ & $10^{-4}$ \\
\hline & Trachea & Carbachol & $97.2 \pm 1.6^{c}$ & $10^{-5}$ \\
\hline & Uterus & Oxytocin & $98.3 \pm 1.2^{\mathrm{c}}$ & $10^{-4}$ \\
\hline & Ileum & Histamine & $45.3 \pm 1.4^{\mathrm{c}}$ & $10^{-4}$ \\
\hline \multirow[t]{4}{*}{11} & Aorta & Phenylephrine & $72.5 \pm 2.8^{\mathrm{b}, \mathrm{c}, \mathrm{d}}$ & $10^{-4}$ \\
\hline & Trachea & Carbachol & $83.3 \pm 1.9^{\mathrm{b}, \mathrm{c}, \mathrm{d}}$ & $10^{-5}$ \\
\hline & Uterus & Oxytocin & $80.5 \pm 1.6^{b, c, d}$ & $10^{-4}$ \\
\hline & Ileum & Histamine & $22.9 \pm 1.4^{\mathrm{b}, \mathrm{c}, \mathrm{d}}$ & $10^{-4}$ \\
\hline \multirow[t]{4}{*}{12} & Aorta & Phenylephrine & $78.7 \pm 2.1^{\mathrm{b}, \mathrm{c}, \mathrm{d}, \mathrm{e}}$ & $10^{-4}$ \\
\hline & Trachea & Carbachol & $90.5 \pm 1.9^{\mathrm{b}, \mathrm{c}, \mathrm{d}}$ & $10^{-5}$ \\
\hline & Uterus & Oxytocin & $94.3 \pm 1.6^{\mathrm{b}, \mathrm{c}, \mathrm{d}}$ & $10^{-4}$ \\
\hline & Ileum & Histamine & $34.7 \pm 2.4^{\mathrm{b}, \mathrm{c}, \mathrm{d}, \mathrm{e}}$ & $10^{-4}$ \\
\hline \multirow[t]{4}{*}{ Scopolamine } & Aorta & Phenylephrine & $82.5 \pm 1.2^{\mathrm{b}, \mathrm{c}, \mathrm{d}, \mathrm{e}}$ & $10^{-4}$ \\
\hline & Trachea & Carbachol & $92.3 \pm 1.4^{\mathrm{b}, \mathrm{c}, \mathrm{d}}$ & $10^{-5}$ \\
\hline & Uterus & Oxytocin & $94.3 \pm 1.2^{\mathrm{b}, \mathrm{c}, \mathrm{d}}$ & $10^{-4}$ \\
\hline & Ileum & Histamine & $60.8 \pm 1.6^{\mathrm{b}, \mathrm{c}, \mathrm{d}, \mathrm{e}}$ & $10^{-4}$ \\
\hline
\end{tabular}

a Mean value \pm SD of five tests, $p<0.05$.

Significant differences $(p<0.05)$ for respective muscles were observed: ${ }^{b, c} \mathbf{5 a}$ and $\mathbf{5 b}$ vs. 11, $\mathbf{1 2}$, scopolamine;

d 11 vs. 12, scopolamine, for all muscles; e 12 vs. scopolamine for aorta and ileum. 
J. A. S. Luis et al.: Synthesis and preliminary ex vivo evaluation of the spasmolytic activity of 1,3-thiazolium- and 1,3,4-thiadiazolium5-methylthio- and 5-thioacetate derivatives, Acta Pharm. 64 (2014) 233-245.

respective agonists. The compounds inhibited more efficiently the contractions in the uterus and trachea (80-98 \%), the ileum being the muscle with lower spasmolytic response (23-45\%). Similar results were obtained with the reference drug scopolamine which was able to inhibit the contractions of the uterus and trachea by 92 and $94 \%$, respectively (higher response), and ileum by $60 \%$ (lower response).

Compounds $\mathbf{5 a}$ and $\mathbf{6 a}$ had the same percentage of inhibition of contractions for all tested muscles, demonstrating no or very little importance of the thioacetate and methylthio groups linked to $\mathrm{C}-5$ for the spasmolytic activity in the case of 1,3-thiazolium derivatives.

For compounds having the 3,4-thiadiazolium system (11 and 12) the presence of the 5-thioacetate group (in 12) proved to be important for increasing the activity, promoting an increase in contraction inhibition in all smooth muscles evaluated, reaching a maximum increase of $50 \%$ for ileum. Among tested compounds, compound $\mathbf{1 1}$ was the least active for three of the four muscles evaluated (trachea, uterus and ileum). However, it exerted higher spasmolytic activity on rat aorta (72 vs. $55 \%$ ) than both 1,3-thiazolium derivatives (5a and $6 \mathbf{a}$ ).

This means that in three of among the four tested muscles (ileum, trachea and uterus), 1,3-thiazolium derivatives (5a, 6a) had superior inhibitory activity over 1,3,4-thiadiazolium derivatives $(\mathbf{1 1}, \mathbf{1 2})$. The aorta was the only exception where $\mathbf{1 1}$ and $\mathbf{1 2}$ showed inhibition greater than $70 \%$ of, whereas compounds 5a and $6 \mathbf{a}$ were able to inhibit contractions by only $55 \%$.

\section{CONCLUSIONS}

All compounds undergoing pharmacological screening in smooth muscle showed good activities in muscles isolated from rats and guinea pigs (aorta, uterus, ileum and trachea). Compounds 5a, 6a and $\mathbf{1 2}$ exhibited a depressant activity equal to or greater than scopolamine in uterus and trachea, indicating that mesoionic derivatives could be promising compounds for the development of new spasmolytic agents. However, further investigation is currently under way in our laboratory in order to determine the $I C_{50}$, toxicity, to check the reversibility of the effect and elucidate the mode of action at the molecular level.

Acknowledgements. - We are indebted for financial support to the Conselho Nacional de Desenvolvimento Científico e Tecnológico $(\mathrm{CNPq})$ and UEPB, through the Programa de Incentivo à Pós-Graduação e Pesquisa/PRPGP.

\section{REFERENCES}

1. L. B. Kier and E. B. Roche, Medicinal chemistry of the mesoionic compounds, J. Pharm. Sci. $\mathbf{5 6}$ (1966) 149-168; DOI: 10.1002/jps.2600560202.

2. M. B. Oliveira, J. Miller, A. B. Pereira, S. E. Galembeck, G. L. C. Moura and A. M. Simas, Mesoionic 2-N-cycloalkylamino-5-alkyl-1,3-dithiolium-4-thiolates, Phosphorus, Sulfur, Silicon Relat. Elem. 108 (1996) 75-84; DOI: 10.1080/10426509608029640. 
3. C. A. C. Bosco, G. S. Maciel, N. Rakov, C. B. Araújo, L. H. Acioli, A. M. Simas, P. F. Athayde-Filho and J. Miller, Probing the nuclear susceptibility of mesoionic compounds using two-beam coupling with chirp-controlled pulses, Chem. Phys. Lett. 449 (2007) 101-106; DOI: 10.1016/ j.cplett.2007.10.037.

4. R. S. T. R. Nascimento, C. R. S. Morais, H. L. Lira, S. A. Morais, P. F. Athayde-Filho, L. F. L. Lucena, A. G. Souza and G. B. Campos, Synthesis and characterization of nanocomplexes of $\mathrm{Eu}(\mathrm{III})$ and $\mathrm{Er}(\mathrm{III})$ coordinate with 2(4-clorophenyl)-3-phenyl-1,3,4-thiadiazoleo-5-tiolate mesoionic, J. Alloys Comp. 495 (2010) 603-605; DOI: 10.1016/j.jallcom.2009.12.003.

5. S. A. Morais, C. R. S. Morais, P. F. Athayde-Filho, B. F. Lira and R. S. T. R. Nascimento, A kinetic study of the thermal decomposition of mesoionic compounds within scope of its application in nonlinear optical devices, J. Therm. Anal. Calorim. 97 (2009) 437-441; DOI: 10.1007/s10973-0090082-8.

6. B. F. Lira, S. A. Morais, G. B. Rocha, J. Miller, G. L. C. Moura, A. M. Simas, C. Peppe and P. F. Athayde-Filho, 1,3-Thiazolium-5-thiolates mesoionic compounds: Semiempirical evaluation of their first static hyperpolarizabilities and synthesis of new examples, J. Braz. Chem. Soc. 21 (2010) 934-940; DOI: 101590/S0103-505320100000500024.

7. A. S.-Ribeiro, A. Echevarria, E. F. Silva, C. R. C. Franco, S. S. Veiga and M. B. M. Oliveira, Cytotoxic effect of a new 1,3,4-thiadiazolium mesoionic compound (MI-D) on cell lines of human melanoma, Br. J. Cancer 91 (2004) 297-304. DOI: 10.1038/sj.bjc.6601946.

8. R. F. Rodrigues, E. F. Silva, A. Echevarria, R. Fajardo-Bonin, V. F. Amaral, L. L. Leon and M. M. Canto-Cavalheiro, A comparative study of mesoionic compounds in Leishmania sp. and toxicity evaluation, Eur. J. Med. Chem. 42 (2007) 1039-1043; DOI: 10.1016/j.ejmech.2006.12.026.

9. R. F. Rodrigues, D. Castro-Pinto, A. Echevarria, C. M. Reis, C. N. Del Cistia, C. M. R. Sant'Anna, F. Teixeira, H. Castro, M. Canto-Cavalheiro, L. L. Leon and A. Tomás, Investigation of tripanothione redutase inhibitory activity by 1,3,4-thiadiazolium-2-aminide derivatives and molecular docking studies, Bioorg. Med. Chem. 20 (2012) 1760-1766; DOI: 10.1016/j.bmc.2012.01.009.

10. K. L. M. Cavalcante, N. A. Correia, K. L. G. Dias, D. F. Silva, J. C. Silva-Filho, I. G. A. Araújo, B. F. Lira, P. F. Athayde-Filho and I. A. Medeiros, Endothelium-derived nitric oxide contributes to the vasorelaxant response induced by mesoionic 2-(4-chlorophenyl)-3-methyl-4-(4-methoxyphenyl)-1,3-thiazolium-5-thyolate (CMMTT) in rats, J. Pharmacol. Sci. 110 (2009) 29-35; DOI: 10.1254/jphs.FP0071581.

11. K. Rehse, T. Ciborski and B. Müller, Platelet aggregation inhibiting and anticoagulant effects of oligoamines. XXVII. Inhibition of leucocyte adherence to endothelium by oligoamine RE 1492C and the NO-donor RE 2047, Arch. Pharm. (Weinheim) 328 (1995) 125-126; DOI: 10.1002/ardp. 19953280206.

12. L. B. Kier and E. B. Roche, Medicinal chemistry of the mesoionic compounds, J. Pharm. Sci. 56 (1967) 149-168; DOI: 10.1002/jps.2600560202.

13. C. S. Oliveira, V. S. Falcão-Silva, J. P. Siqueira-Júnior, D. P. Harding, B. F. Lira, J. G. F. Lorenzo, J. M. Barbosa-Filho and P. F. Athayde-Filho, Drug resistance modulation in Staphylococcus aureus, a new biological activity for mesoionic hydrochloride compounds, Molecules 16 (2011) 2023-2031; DOI: $10.3390 /$ molecules16032023.

14. B. F. Lira, J. Miller, A. M. Simas, P. F. Athayde-Filho, A. F. Dias, R. O. Silva and V. C. Oliveira, Synthesis and complete assignments of $1 \mathrm{H}$ and 13C-NMR spectra of mesoionic 2-(p-trifluoromethylphenyl)-3-methyl-4-( $p$-tolyl)-1,3-thiazolium-5-thiolate and 2-( $p$-chlorophenyl)-3-methyl4-( $p$-isopropylphenyl)-1,3-thiazolium-5-thiolate, Arkivoc vi (2004) 12-21.

15. P. F. Athayde-Filho, J. Miller, A. M. Simas, K. X. F. R. Sena and A. A. Chiappeta, Synthesis, characterization and evaluation of the activity of ten mesoionic compounds against microorganisms, Lat. Am. J. Pharm. 18 (1999) 17-22. 
16. J. T. Lima J. R. G. S. Almeida, K. S. L. Mota, A. S. S. C. Lúcio, C. A. Câmara, J. M. B. Filho and B. A. Silva, Selective spasmolytic effect of a new furanoflavoquinone derivative from diplotropin on guinea-pig trachea, J. Chem. Pharm. Res. 3 (2011) 249-258.

17. E. E. Daniel, C. Y. Kwan and L. Janssen, Pharmacological techniques for the in vitro study of intestinal smooth muscles, J. Pharmacol. Toxicol. Meth. 45 (2001) 141-158.

18. B. M. Altura and B. T. Altura, Differential effects of substrate depletion on drug-induced contractions of rabbit aorta, Am. J. Physiol. 219 (1970) 1698-1705.

19. E. Tschirhart, N. Frossard, C. Bertrand and Y. Landry, Arachidonic acid metabolites and airway epithelium-dependent relaxant factor, J. Pharmacol. Exp. Ther. 243 (1987) 310-316. 